\title{
PENGARUH GENDER, KOMPLEKSITAS TUGAS, PENGALAMAN AUDITOR, DAN KOMPETENSI PROFESIONAL TERHADAP AUDIT JUDGEMENT
}

\author{
Ardiani Ika Sulistyawati , Aprih Santoso, Dina Sita Prastiti \\ Fakultas Ekonomi \\ Universitas Negeri Semarang \\ A R T I C LE IN F O
}

Keywords: Gender, Task,

Experience, Competence, Audit.

Kata Kunci: gender, tugas, pengalaman, kompetensi, audit

Corresponding author :

Ardiani Ika Sulistyawati ardiani@usm.ac.id

\begin{abstract}
This study aims to examine and analyze the effects of Gender, Complexity of Duties, Experience Auditors, and Professional Competence of Judgment Audit. This research uses a sample of auditors who work at Public Accounting Firm in Central Java and DIY Provinces. This experience was carried out using a questionnaire at Public Accounting Firm in Central Java and Yogyakarta with 89 respondents. Of the 121 questionnaires distributed, only 89 questionnaires could be used. Data analysis techniques in this study using multiple linear regression analysis, Test Validity and Realibility Test. In addition all variables have been tested using Classic Assumption Test.Based on t test by using multiple regression model indicate that task complexity, auditor experience and professional competence have an effect on audit judgment, while gender does not affect to audit judgment.
\end{abstract}

Abstrak: Penelitian ini bertujuan untuk menguji dan menganalisis pengaruh Gender, Kompleksitas Tugas, Pengalaman Auditor, dan Kompetensi Profseional terhadap Audit Judgement. Penlitian ini menggunakan sampl auditor yang bekerja pada Kantor Akuntan Publik di Provinsi Jawa Tengah dan DIY.Pengalaman ini dilaksanakan menggunakan kuesioner di Kantor Akuntan Publik di Jawa Tengah dan DIY dengan menggunakan 89 responden. Dari 121 kuesioner yang didistribusikan, hanya 89 kuesioner yang dapat digunakan. Teknik analisis data dalam penelitian ini menggunakan analisis regresi linier berganda, Uji Validitas dan Uji Realibilitas. Selain itu semua variabel telah diuji dengan menggunakan Uji Asumsi Klasik. Berdasarkan uji $t$ dengan menggunakan model regresi berganda menunjukkan bahwa kompleksitas tugas, pengalaman auditor dan kompetensi profesional berpengaruh terhadap audit judgement, sedangkan gender tidak bepengaruh terhadap audit judgement. 


\section{Latar Belakang}

\section{PENDAHULUAN}

Auditing sebagai suatu proses sistematik untuk memperoleh dan mengevaluasi bukti secara objektif mengenai pernyataan-pernyataan tentang kejadian atau kegiatan ekonomi, dengan tujuan untuk menetapkan tingkat kesesuaian antara pernyataan-pernyataan tersebut dengan kriteria yang telah ditetapkan, serta penyampaian hasilhasilnya kepada pemakai yang berkepentingan (Mulyadi, 2002). Profesi akuntan publik merupakan kepercayaan masyarakat. Dari profesi akuntan publik, masyarakat mengharapkan penilaian yang bebas dan tidak memihak terhadap informasi yang disajikan oleh manajemen perusahaan dalam laporan keuangan (Mulyadi, 2002)

Salah satu peran jasa akuntan publik adalah memberikan jaminan kepada stakeholder bahwa informasi yang disajikan dalam laporan keuangan perusahaan adalah akurat dan dapat dipercaya sebagai dasar untuk pengambilan keputusan. Menurut Financial Accounting Standards Board (FASB) danInternational Accounting Standard Board $(I A S B)$ dalam kerangka konseptual laporan keuangan menyatakan bahwa laporan keuangan harus memenuhi karakteristik kualitatif fundamental yaitu relevan dan penyajian yang jujur. Kedua karakteristik tersebut harus dipenuhi oleh laporan keuangan agar dapat memenuhi tujuannya memberikan informasi yang dijadikan dasar dalam pengambilan keputusan. Kedua karakteristik tersebut sulit diukur oleh para pengguna informasi sehingga dibutuhkan jasa pihak ketiga yaitu auditor independen yaitu auditor eksternal yang bersifat independen untuk memberi jaminan bahwa laporan keuangan tersebut relevan dan telah disajikan dengan jujur. Jaminan dari auditor independen akan meningkatkan kepercayaan para pemangku kepentingan terhadap informasi yang disajikan.

Pentingnya peran dan kepercayaan yang besar terhadap profesi akuntan publik mengharuskan akuntan publik untuk memperhatikan audit judgement yang dihasilkannya. Untuk melaksanakan tugas audit, dibutuhkan sebuah audit judgement ketika auditor mengumpulkan bukti dalam waktu yang berbeda dan mengintegrasikan informasi dari bukti tersebut. Jika seorang auditor melakukan judgement yang kurang tepat, maka akan berpengaruh terhadap ketepatan opini akhir mengenai kewajaran laporan keuangan. Seperti yang disebutkan oleh Standar Professional Akuntan Publik (SPAP) seksi 341 bahwa dalam menjalankan proses audit, auditor akan memberikan pendapat dengan judgement berdasarkan kejadian-kejadian yang dialami oleh suatu kesatuan usaha pada masa lalu, masa kini dan di masa yang akan datang.

Beberapa kasus kegagalan audit banyak terjadi di dunia, dimulai dari kasus besar Enron pada tahun 2001 yang juga melibatkan KAP besar Arthur Enderson dalam upaya memanipulasi laba perusahaan. Selain itu dilanjutkan kasus Satyam Computer Service pada tahun 2009 di India yang melakukan penipuan dengan menggunakan dokumen-dokumen palsu, memalsukan rekening bank dan menyembunyikan berbagai bukti guna melakukan penggelembungan laba. Price Waterhouse Cooper sebagai auditor dari Satyam selama 8 tahun terakhir dinilai juga terlibat dan gagal melakukan tugas auditnya. Kasus akuntansi besar yang baru terungkap di tahun 2015 menimpa perusahaan besar di Jepang yaitu Toshiba. Perusahaan tersebut terbukti melakukan penggelembungan laba sejak tahun 2008. Dalam kasus Toshiba tersebut, beberapa pihak petinggi perusahaan ikut terlibat dan terjadi secara sistematis sehingga auditor eksternal Toshiba yaitu Ernst \& Young yang merupakan salah satu KAP Big Four tidak dapat mendeteksi kecurangan tersebut.

Terdapat beberapa penelitian mengenai faktor- faktor yang mempengaruhi audit judgement memiliki kesimpulan yang berbeda. Melihat banyaknya faktor yang dapat mempengaruhi audit judgement, maka perlu diadakan perumusan masalah pada faktor- faktor sepertiGender, Kompleksitas tugas, Pengalaman auditor dan Kompetensi profesional yang dianggap berpengaruh terhadap Audit Judgement. Sehingga dapat dirumuskan masalah adalah"Apakah Gender, Kompleksitas tugas, Pengalaman auditor dan Kompetensi profesional berpengaruh terhadap Audit Judgement?”.

\section{Teori atribusi}

\section{TINJAUAN PUSTAKA DAN PENGEMBANGAN HIPOTESIS}

Teori atribusi pertama kali dikembangkan oleh Fritz Heider pada tahun 1958 dari tulisannya yang berjudul "Psychology of Interpersonal relations". Atribusi berarti upaya untuk memahami penyebab dibalik perilaku orang lain, dan dalam beberapa kasus juga penyebab dibalik perilaku kita sendiri. Teori atribusi merupakan teori kontemporer yang paling berpengaruh dengan implikasi untuk motivasi akademik (Weiner, 1980 dalam Wahyudi, $\mathrm{dkk}$, 2013). Artinya teori tersebut menekankan gagasan bahwa seseorang termotivasi dengan hasil yang menyenangkan untuk dapat merasa lebih baik akan dirinya sendiri. Atribusi mengacu kepada penyebab suatu kejadian atau hasil yang diperoleh berdasarkan persepsi individu. 
Ada tiga faktor yang menjadi dasar pertimbangan untuk menentukan perilaku individu tersebut dipengaruhi secara internal atau eksternal, yaitu (1) Distinctiveness(keunikan). Hal ini berarti apakah individu memiliki perilaku yang berbeda dalam situasi yang berbeda; (2) Consensus. Jika seseorang dihadapkan pada situasi yang sama meresponnya dengan cara yang sama, maka perilaku ini menunjukkan consensus; dan (3) Consistencyberarti derajat kesamaan reaksi seseorang terhadap stimulus atau peristiwa yang sama pada waktu yang berbeda.

Hanjani (2014) menyebutkan bahwa teori atribusi menjelaskan tentang pemahaman akan reaksi seseorang terhadap peristiwa di sekitar mereka, dengan mengetahui alasan-alasan mereka atas kejadian yang dialami. Teori atribusi dijelaskan bahwa terdapat perilaku yang berhubungan dengan sikap dan karakteristik individu, maka dapat dikatakan bahwa hanya melihat perilakunya akan dapat diketahui sikap atau karakteristik orang tersebut serta dapat juga memprediksi perilaku seseorang dalam menghadapi situasi tertentu.

Teori atribusi menjelaskan tentang pemahaman akan reaksi seseorang terhadap peristiwa di sekitar mereka, dengan mengetahui alasan-alasan mereka atas kejadian yang dialami. Teori atribusi dijelaskan bahwa terdapat perilaku yang berhubungan dengan sikap dan karakteristik individu, maka dapat dikatakan bahwa hanya melihat perilakunya akan dapat diketahui sikap atau karakteristik orang tersebut serta dapat juga memprediksi perilaku seseorang dalam menghadapi situasi tertentu.

Dalam penelitian ini, peneliti menggunakan teori atribusi karena peneliti akan melakukan studi empiris untuk mengetahui faktor-faktor yang mempengaruhi auditor terhadap kualitas hasil audit, khususnya pada karakteristik personal seorang auditor itu sendiri. Pada dasarnya karakteristik personal auditor merupakan salah satu penentu terhadap kualitas hasil audit dan judgement yang diberikan karnea merupakan suatu faktor internal yang mendorong seseorang untuk melakukan suatu aktivitas.

\section{Audit Judgement}

Audit judgementmerupakan suatu pertimbangan pribadi atau cara pandang auditor dalam menanggapi informasi yang mempengaruhi dokumentasi bukti serta pembuatan keputusan pendapat auditor atas laporan keuangan suatu entitas. Cara pandang auditor dalam menanggapi informasi berhubungan dengan tanggung jawab dan risiko audit yang akan dihadapi oleh auditor sehubungan dengan judgement yang dibuatnya (Jamilah dkk dalam Margaret, 2014).

Standar Profesi Akuntan Publik SPAP pada seksi 341 juga menyebutkan bahwa audit judgement atas kemampuan kesatuan usaha dalam mempertahankan kelangsungan hidupnya harus berdasarkan pada ada tidaknya kesangsian dalam diri auditor itu sendiri terhadap kemampuan suatu kesatuan usaha dalam mempertahankan kelangsungan hidupnya dalam periode satu tahun sejak tanggal laporan keuangan auditan.

Menurut Fitriana, dkk (2014), audit judgement adalah suatu pertimbangan yang mempengaruhi dokumentasi audit dan keputusan pendapat yang dibuat oleh auditor. Audit judgement melekat pada setiap tahap dalam proses audit laporan keuangan, mulai dari penerimaan perikatan audit, perencanaan audit pelaksanaan pengujian audit dan pelaporan audit. Audit judgement diperlukan dalam proses audit karena audit tidak dilakukan terhadap seluruh bukti transaksi dalam perusahaan melainkan hanya sampel yang memadai. Berdasarkan sampel bukti tersebut auditor akan memberikan pendapat atas laporan keuangan auditan perusahaan, sehingga dapat dikatakan bahwa audit judgement sangat menentukan hasil dari pelaksanaan audit (Sofiani dan Tjondro, 2014).

Audit judgement diperlukan karena audit tidak dilakukan terhadap seluruh bukti. Bukti inilah yang digunakan untuk menyatakan pendapat atas laporan keuangan auditan, sehingga dapat dikatakan bahwa audit judgement ikut menentukan hasil dari pelaksanaan audit. Rochmawati dalam Praditaningrum (2012) menjelaskan tahapan-tahapan yang dilakukan pada saat melakukan audit judgement yaitu merumuskan persoalan, mengumpulkan informasi yang relevan, mencari alternatif tindakan, menganalisis alternatif yang fleksibel, memilih alternatif yang terbaik, kemudian pelaksanaan dan evaluasi hasilnya.

Dalam standar pemeriksaan Badan Pemeriksa Keuangan dijelaskan bahwa pemeriksa harus menggunakan pertimbangan profesionalnya untuk menentukan hal-hal yang terkait dengan pemeriksaan yang dilakukan, baik dalam pemeriksaan keuangan, pemeriksaan kinerja, dan pemeriksaan dengan tujuan tertentu. Pertimbangan profesional tersebut diantaranya berkaitan dengan gangguan terhadap independensi, pertimbangan tentang hasil pemeriksaan sebelumnya serta tindak lanjut atas rekomendasi yang berkaitan dengan tujuan pemeriksaan yang dilaksanakan, pertimbangan profesionalnya terhadap prosedur pemeriksaan yang dirancang untuk menilai salah saji material dan mempertimbangkan pengendalian intern dari entitas yang diperiksa. 
Pemeriksa dalam mengaudit berpedoman terhadap petunjuk pelaksanaan pemeriksaan dan petunjuk teknis pemeriksaan (Margaret, 2014). Dua petunjuk ini mengatur pemahaman atas sistem pengendalian intern, pemahaman dan penilaian risiko, penetapan materialitas awal dan kesalahan tertoleransi dan penentuan metode uji petik untuk melaksanakan pemeriksaan yang hasil laporannya menjadi patokan bagi pemeriksa dalam pembuatan judgement.

Puspitasari (2010) dalam Rizkiyana (2013) menjelaskan judgement sebagai perilaku berpengaruh dalam mempersiapkan situasi, dimana faktor utama yang mempengaruhinya adalah materialitas dan apa yang diyakini sebagai kebenaran, sebagaimana paparan berikut:

1. Materialitas

Dalam auditing materialitas sangat penting signifikan dan esensial tapi dalam konsepnya tidak terdapat aturan pengukurannya sehingga tergantung pada pertimbangan auditor (Mutmainah, 2006 dalam Rizkiyana (2013).

2. The Faith Syndrome

Satu persepsi kondisi yang dapat mengaruh pada berubahnya perilaku auditor yaitu halo effect, Efek yang positif tapi terkadang merupakan persepsi yang keliru tentang orang lain (Mutmainah, 2006 dalam Rizkiyana, 2013). Simpulan audit biasanya didasarkan pada siapa yang telah melakukan pekerjaan audit sebelumnya. Jika auditor memiliki keyakinan tentang orang tersebut halo effect diterapkan pada auditor lama dan pekerjaan mereka. Judgement audit cenderung dipengaruhi oleh persepsi aktivitas sebelumnya.

\section{Gender Terhadap Audit Judgement}

Istilah gender dapat diartikan sebagai pembedaan peran antara laki-laki dan perempuan yang tidak hanya mengacu pada perbedaan biologisnya/ seksualnya, tetapi juga mencakup nilai-nilai sosial budaya (Berninghausen and Kerstan, 1992) dalam Sabaruddinsah (2007).

Meyers-Levy (1986) dalam Zulaikha (2006) mengembangkan kerangka teoritis untuk menjelaskan kajian tentang perbedaan antara perempuan dan laki-laki dalam memproses informasi. Kerangka teoritis ini mereka sebut dengan "selectivity hypothesis". Perbedaaan yang didasarkan pada isu gender dalam pemrosesan informasi dan pembuatan keputusan didasarkan atas pendekatan yang berbeda yaitu bahwa laki-laki dan perempuan menggunakan pemrosesan inti informasi dalam memecahkan masalah dan membuat inti keputusan. Laki-laki pada umumnya dalam menyelesaikan masalah tidak menggunakan semua informasi yang tersedia, dan mereka juga tidak memproses informasi secara menyeluruh, sehingga dikatakan bahwa laki-laki cenderung melakukan pemrosesan informasi secara terbatas. Sedangkan perempuan dipandang sebagai pemroses informasi lebih detail yang melakukan proses informasi pada sebagian besar inti informasi untuk pembuatan keputusan atau judgement.

Pengambilan keputusan harus didukung oleh informasi yang memadai. Kaum pria dalam pengolahan informasi tersebut biasanya tidak menggunakan seluruh informasi yang tersedia sehingga keputusan yang diambil kurang komprehensif. Lain halnya dengan wanita, mereka dalam mengolah informasi cenderung lebih teliti dengan menggunakan informasi yang lebih lengkap dan mengevaluasi kembali informasi tersebut dan tidak gampang menyerah (Mayer dan Levy, 1986 dalam Jamillah dkk, 2007). Selain itu, kaum wanita lebih juga memiliki daya ingat yang lebih tajam terhadap suatu informasi baru dibandingkan kaum pria dan kemampuan mengolah informasi yang sedikit tersebut menjadi lebih tajam (Yendrawati dan Mukti, 2015) . Praditaningrum dan Januari (2011) menunjukkan bahwa gender berpengaruh terhadap audit judgement. Dari uraian diatas dapat dirumuskan hipotesis penelitian sebagai berikut :

H1 : Gender berpengaruh terhadap Audit judgement

\section{Kompleksitas Tugas Terhadap Audit Judgement}

Hasil penelitian Chung dan Monroe (2001) mengatakan bahwa kompleksitas tugas yang tinggi berpengaruh terhadap judgement yang diambil oleh auditor. Auditor merasa bahwa tugas audit yang dihadapinya merupakan tugas yang kompleks sehingga auditor mengalami kesulitan dalam melakukan tugas dan tidak dapat membuat judgement profesional. Hal serupa juga ditunjukan dalam penelitian Wijayatri (2010) yang menjelaskan bahwa kompleksitas tugas memiliki pengaruh yang paling dominan terhadap audit judgement. Akibatnya judgement yang diambil oleh auditor tersebut menjadi tidak sesuai dengan bukti yang diperoleh.

Auditor selalu dihadapkan dengan tugas-tugas yang banyak, berbeda- beda, dan saling terkait satu sama lainnya. Restuningdiah dan Indriantoro (2000) menyatakan bahwa kompleksitas muncul dari ambiguitas dan struktur yang lemah, baik dalam tugas-tugas utama maupun tugas-tugas lain. Kompleksitas tugas telah menjadi 
variabel penting dalam penelitian tentang penetapan tujuan, pengambilan keputusan, dan kinerja (Sanusi, 2007). Dalam kasus lingkungan audit, penting untuk mempelajari kompleksitas tugas karena kompleksitas tugas dapat berdampak pada kinerja audit judgement, dan pemahaman mengenai kompleksitas tugas-tugas audit yang berbeda dapat membantu para manajer membuat tugas lebih baik dalam pelatihan pengambilan keputusan (Nadhiroh, 2010).

Kompleksitas tugas menunjukan tingkat inovasi dan pertimbangan audit yang diperlukan oleh staf pemeriksa dalam menyelesaikan tugas yang dibebankan. Kompleksitas tugas semakin tinggi ketika tugas yang diterima semakin sulit, tidak terstruktur dan membingungkan. Tingginya kompleksitas tugas akan berdampak pada menurunnya usaha dan motivasi kerja sehingga penurunan kinerja akan terjadi, jika kinerja menurun akan menyebabkan judgement kurang baik. Hal ini didukung oleh penelitian sebelumnya yaitu Raiyani dan Saputra (2014) yang menyatakan kompleksitas tugas berpengaruh secara signifikan terhadap audit judgement. Dari uraian diatas dapat dirumuskan hipotesis penelitian sebagai berikut :

H2 : Kompleksitas tugas berpengaruh terhadap Audit Judgement

\section{Pengalaman Auditor Terhadap Audit Judgement}

Pengalaman membentuk seorang auditor menjadi terbiasa dengan situasi dan keadaan dalam setiap penugasan. Kusharyanti (2003) menemukan bahwa auditor yang berpengalaman mempunyai pemahaman yang lebih baik. Kenyataan menunjukkan semakin lama seseorang bekerja maka semakin banyak pengalaman kerja yang dimiliki oleh pekerja tersebut. Sebaliknya, semakin singkat masa kerja seseorang biasanya semakin sedikit pula pengalaman yang diperolehnya.

Penelitian oleh Zulaikha (2006) juga menjelaskan bahwa pengalaman auditor memiliki pengaruh terhadap audit judgement, dimana dalam penugasan audit utamanya perlu memperhatikan pengalamannya sebagai auditor. Elisabeth (2012) dalam Raiyani dan Saputra (2014) menyatakan bahwa selain pengetahuan, pengalaman juga dapat mempengaruhi kemampuan seorang auditor dalam memberikan judgement dengan memprediksi kecurangan yang terjadi dalam perusahaan. Dari pengalaman tersebut auditor dapat belajar bagaimana cara melakukan suatu judgement. Hasil ini mendukung penelitian yang dilakukan oleh Sularso dan Na'im (1999) dalam Sabaruddinsah (2007) yang memperlihatkan bahwa seseorang dengan lebih banyak pengalaman dalam suatu bidang memiliki lebih banyak hal yang tersimpan dalam ingatannya dan dapat mengembangkan suatu pemahaman yang baik mengenai peristiwa-peristiwa.

Menurut Asih (2006), pengalaman mengarah kepada proses pembelajaran dan pertambahan potensi bertingkah laku dari pendidikan formal maupun nonformal atau bisa diartikan sebagai suatu proses peningkatan pola tingkah laku. Ariyanti, Sujana dan Darmawan (2014) serta Sofiani dan Tjondro (2014) berhasil membuktikan adanya pengaruh positif yang signifikan antara pengalaman auditor terhadap audit judgement. Seorang auditor yang berpegalaman akan semakin peka dalam memahami setiap informasi yang relevan sehubungan dengan keputusan yang diambillnya, dikarenakan auditor yang berpengalaman memiliki lebih banyak hal yang tersimpan dalam ingatannya dan dapat mengembangkan suatu pemahaman yang baik mengenai peristiwa-peristiwa yang terjadi. Dengan demikian, maka auditor yang berpengalaman dapat menghasilkan judgement yang lebih tepat dibandingkan auditor yang kurang berpengalaman. Dari uraian diatas dapat dirumuskan hipotesis penelitian sebagai berikut :

H3 : Pengalaman auditor berpengaruh terhadap Audit Judgement

\section{Kompetensi Profesional Terhadap Audit Judgement}

Standar umum pertama menyebutkan bahwa audit harus dilaksanakan oleh seorang atau lebih yang memiliki keahlian dan pelatihan teknis yang cukup sebagai auditor,sedangkan standar umum ketiga menyebutkan bahwa dalam pelaksanaan audit dan penyusunan laporannya, auditor wajib menggunakan kemahiran profesionalnya dengan cermat dan seksama (SPAP, 2011). Agusti dan Putri (2013) mengemukakan bahwa kompetensi auditor adalah auditor yang dengan pengetahuan dan pengalamannya yang cukup dan eksplisit dapat melakukan audit secara objektif, cermat dan seksama. Sedangkan Nirmala dan Cahyonowati (2013) menemukan bahwa auditor berpengalaman mempunyai pemahaman yang lebih baik. Institut Akuntan Publik Indonesia dalam SPAP (2011) mengemukakan prinsip kompetensi serta sikap kecermatan dan kehati-hatian professional diwajibkan untuk setiap praktisi, bertujuan untuk : (1) Memelihara pengetahuan dan keahlian professional yang dibutuhkan untuk menjamin pemberian jasa professional yang kompeten kepada klien atau pemberi kerja, dan (2) Menggunakan kemahiran profesionalnya dengan seksama sesuai dengan Standar profesi dan etika profesi yang berlaku dalam pemberian jasa profesionalnya. 
Menurut Zu'amah (2009) kompetensi adalah keahlian profesional seorang auditor yang didapat melalui pendidikan formal, uji profesional maupun keikusertaan dalam pelatihan, seminar, dan simposium. Kompetensi yang dibutuhkan dalam melakukan audit yaitu pengetahuan dan kemampuan. Auditor harus memiliki kemampuan untuk bekerja sama dalam tim serta kemampuan dalam menganalisa permasalahan. Kompetensi profesional berpengaruh positif terhadap audit judgement karena semakin tinggi kompetensi auditor akan semakin baik Judgement (pertimbangan) yang akan dihasilkan oleh auditor tersebut.

Trotter (1986) dalam Mayangsari (2003) mendefinisikan bahwa manusia yang berkompeten adalah orang yang dengan keterampilannya mengajarkan pekerjaannya dengan mudah, cepat, intuitif dan sangat jarang atau bahkan tidak pernah membuat kesalahan. Kompetensi auditor merupakan salah satu faktor yang dapat melatarbelakangi seorang auditor dalam menentukan judgment auditnya, karena dalam standar kompetensi auditor terdapat aspek pengetahuan, keahlian, serta sikap personal auditor itu sendiri. Dimana tinggi rendahnya kompetensi yang dimiliki oleh auditor akan berdampak pada pertimbangan audit. Penelitian yang telah dilakukan oleh Raiyani dan Saputra (2014) membuktikan bahwa kompetensi yang dimiliki auditor dapat mempengaruhi pembuatan audit judgement yang dilakukan auditor. Dari uraian diatas dapat dirumuskan hipotesis penelitian sebagai berikut :

H4 : Kompetensi auditor berpengaruh terhadap Audit judgement

\section{METODE PENELITIAN}

\section{Metode pengumpulan data}

Metode pengumpulan data menggunakan kuesioner dan diuji dengan program SPSS 23.

\section{Populasi dan Sampel}

Populasi dalam penelitian ini yaitu seluruh auditor yang bekerja di KAP di Provinsi Jawa Tengah dan DIY. Penelitian ini memilih KAP di Provinsi Jawa Tengah dan DIY dikarenakan provinsi ini mempunyai banyak Kantor Akuntan Publik (KAP) besar maupun Kantor Akuntan Publik (KAP) kecil. Teknik penentuan sampel penelitian ini menggunakan metode Purposive Sampling.Sampel dalam penelitian ini adalah auditor yang bekerja di KAP di Provinsi Jawa Tengah dan DIY. Penelitian menyebar 121 kuesioner kepada KAP (Kantor Akuntan Publik) di Jawa Tengah dan DIY dan kuesioner yang dapat diolah 89 kuesioner sedangkan yang tidak kembali 25 kuesioner.

\section{Variabel Penelitian dan Definisi Operasional Variabel Audit Judgement (Y)}

Audit judgement merupakan suatu pertimbangan pribadi atau cara pandang auditor dalam menanggapi informasi yang mempengaruhi dokumentasi bukti serta pembuatan keputusan pendapat auditor atas laporan keuangan suatu entitas. Cara pandang auditor dalam menanggapi informasi berhubungan dengan tanggung jawab dan risiko audit yang akan dihadapi oleh auditor sehubungan dengan judgment yang dibuatnya (Jamilah dkk dalam Margaret, 2014).

\section{Gender (X1)}

Gender adalah suatu konsep analitis yang digunakan utuk mengidentifikasi perbedaan laki-laki dan perempuan dilihat dari sudut non-biologis, yaitu aspek sosial, budaya maupun psikologis (Mutmainah (2007) dalam Tobing (2012). Perbedaan gender dapat mengakibatkan karakteristik dalam reaksi dan sikap terhadap suatu informasi atau kejadian. Gender wanita dianggap lebih akspresif dalam menyampaikan emosi dan mood yang mereka rasakan. Selain itu wanita juga dianggap lebih mampu membaca perasaan lawan bicara baik secara verbal maupun inverbal (Hanggraeni, 2011).

\section{Kompleksitas Tugas (X2)}

Irwanti (2011) dalam Fitriana dkk (2014) bahwa kompleksitas tugas adalah persepsi individu tentang kesulitan suatu tugas yang disebabkan oleh terbatasnya kepastian dan daya ingat serta kemampuan untuk mengintegrassikan masalah yang dimiliki oleh seorang pembuat keputusan. Auditor eksternal seringkali dihadapkan pada tugas-tugas yang banyak dalam kuantitas maupun jenis yang berbeda-beda serta saling terkait satu sama lain. Menurut Jamilah dkk (2007), tingkat kesulitan tugas dan struktur tugas merupakan dua aspek penyusun dari kompleksitas tugas. Tingkat sulitnya tugas umumnya dikaitkan dengan banyaknya informasi tentang tugas tersebut, sementara sturktur tugas terkait dengan jelas atau tidaknya informasi tersedia terkait pekerjaan tersebut. 


\section{Pengalaman Auditor (X3)}

Pengalaman auditor adalah pengalaman dalam melakukan audit laporan keuangan baik dari segi waktu, jumlah penugasan maupun jenis-jenis perusahaan yang pernah ditangani Menurut Herliansyah dan Meifida (2006) auditor yang berpengalaman akan membuat keputusan yang lebih baik dibandingkan dengan auditor yang belum berpengalaman. Untuk dapat mengukur pengalaman auditor dapat dilihat dari periode lamanya masa kerja auditor serta jumlah penugasan audit yang diterimanya (Asih, 2006).

\section{Kompetensi Profesional (X4)}

Kompleksitas tugas adalah persepsi individu tentang kesulitasn suatu tugas yang disebabkan oleh terbatasnya kapasitas dan daya ingat serta kemampuan untuk mengintegrasikan masalah yang dimiliki oleh seorang pembuat keputusan (Irwanti, 2011).

\begin{tabular}{|c|c|c|}
\hline & \multicolumn{2}{|c|}{$Y=b_{1} X_{1}+b_{2} X_{2}+b_{3} X_{3}+b_{4} X_{4}+e$} \\
\hline Dimana : & $\begin{array}{l}\mathrm{Y} \\
\mathrm{b} \\
\mathrm{X} 1 \\
\mathrm{X} 2 \\
\mathrm{X} 3 \\
\mathrm{X} 4 \\
\mathrm{e}\end{array}$ & $\begin{array}{l}\text { : Audit Judgement } \\
: \text { Koefisien regresi } \\
: \text { Gender } \\
: \text { Kompleksitas tugas } \\
\text { : Pengalaman Auditor } \\
: \text { Kompetensi Profesional } \\
: \text { error }\end{array}$ \\
\hline
\end{tabular}

\section{HASIL PENELITIAN DAN PEMBAHASAN}

\section{UjiAsumsiKlasik}

Dalam penelitian ini, uji asumsi klasik yang dilakukan meliputi: uji normalitas, multikolinearitas dan heteroskedastisitas.

\section{Tabel 1 UjiKolmogorov-SmirnovTest}

\begin{tabular}{|c|c|c|}
\hline & & $\begin{array}{l}\text { Unstandardiz } \\
\text { ed Residual }\end{array}$ \\
\hline $\mathrm{N}$ & & 89 \\
\hline \multirow[t]{2}{*}{ Normal Parameters ${ }^{a, b}$} & Mean & OE- 7 \\
\hline & Std. Deviation & 2,08030173 \\
\hline \multirow[t]{3}{*}{ Most Extreme Differences } & Absolute &, 046 \\
\hline & Positive &, 042 \\
\hline & Negative &,- 046 \\
\hline Kolmogorov-Smirnov $z$ & &, 436 \\
\hline Asymp. Sig. (2-tailed) & & ,991 \\
\hline
\end{tabular}

.Tabel 1 menunjukkan bahwa hasil pengujian Kolmogorov-Smirnov diperoleh nilai Z sebesar 0,436 dan nilai signifikan sebesar 0,991. Oleh karena nilai signifikan lebih besar dari 0,05, maka dapat dikatakan bahwa data residual berdistribusi normal dan sehingga model regresi layak dipakai dan dapat dilanjutkan ke tahap selanjutnya karena telah memenuhi asumsi normalitas. 
Tabel 2 Hasil Uji Multikolinieritas

\begin{tabular}{|c|c|c|c|c|c|c|c|c|}
\hline \multicolumn{9}{|c|}{ Coefficients $^{a}$} \\
\hline & & \multicolumn{2}{|c|}{ Unstandardized Coefficients } & \multirow{2}{*}{$\begin{array}{c}\begin{array}{c}\text { Standardized } \\
\text { Coefficients }\end{array} \\
\text { Beta }\end{array}$} & \multirow[b]{2}{*}{$\mathrm{t}$} & \multirow[b]{2}{*}{ Sig. } & \multicolumn{2}{|c|}{ Collinearity Statistics } \\
\hline \multicolumn{2}{|c|}{ Model } & $\mathrm{B}$ & Std. Error & & & & Tolerance & VIF \\
\hline \multirow[t]{5}{*}{1} & (Constant) & $-13,617$ & 3,001 & & $-4,538$ &, 000 & & \\
\hline & Gender &, 204 & 468 &, 036 &, 435 &, 665 &, 944 & 1,060 \\
\hline & Kompleksitas Tugas &, 149 &, 051 &, 244 & 2,926 &, 004 &, 918 & 1,089 \\
\hline & Pengalaman Auditor &, 217 &, 044 & ,414 & 4,952 &, 000 &, 917 & 1,091 \\
\hline & Kompetensi Profesional & ,411 &, 060 &, 568 & 6,795 &, 000 &, 914 & 1,094 \\
\hline
\end{tabular}

a. Dependent Variable: Audit Judgement

Tabel 2 menunjukkan bahwa dari hasil analisi yang diperoleh menunjukkan bahwa semua variabel memiliki nilai tolerance lebih besar dari 0,10 dan nilai Variance Inflation Factor (VIF) lebih kecil dari 10. Sehingga pada model regresi yang digunakan dalam penelitian ini tidak terjadi multikolonieritas.

\section{Tabel 3 Uji Glejser}

\begin{tabular}{|c|c|c|c|c|c|c|}
\hline \multicolumn{7}{|c|}{ Coefficients $^{a}$} \\
\hline \multirow{2}{*}{\multicolumn{2}{|c|}{ Model }} & \multicolumn{2}{|c|}{ Unstandardized Coefficients } & \multirow{2}{*}{$\begin{array}{c}\begin{array}{c}\text { Standardized } \\
\text { Coefficients }\end{array} \\
\text { Beta }\end{array}$} & \multirow[b]{2}{*}{$\mathrm{t}$} & \multirow[b]{2}{*}{ Sig. } \\
\hline & & $\mathrm{B}$ & Std. Error & & & \\
\hline \multirow[t]{5}{*}{1} & (Constant) & 1,120 & 1,754 & &, 638 &, 525 \\
\hline & Gender &,- 472 &, 274 &,- 188 & $-1,723$ &, 089 \\
\hline & Kompleksitas Tugas &, 038 &, 030 &, 142 & 1,286 &, 202 \\
\hline & Pengalaman Auditor &,- 011 &, 026 &,- 048 &,- 436 &, 664 \\
\hline & Kompetensi Profesional &, 033 &, 035 & 103 & ,929 &, 355 \\
\hline
\end{tabular}

a. Dependent Variable: AbsUi

Dilihat dari tabel di atas dengan menggunakan Uji Glajser terlihat nilai signifikansinya di atas 0,05. Maka dapat disimpulkan seluruh variabel independen yang digunakan dalam penelitian ini sudah terbebas dari gejala heteroskedastisitas. Hal ini konsisten dengan hasil uji Scatterplots.

\section{Uji Kelayakan Model}

Berikutnya untuk menguji besarnya kontribusi dan kelayakan dari model penelitian ini maka dapat dilihat dari hasil pada tabel 4 model summary dan tabel 5 uji F berikut ini:

\section{Tabel 4 Model Summary}

Model Summary ${ }^{b}$

\begin{tabular}{|l|r|r|r|r|}
\hline Model & $\mathrm{R}$ & $\mathrm{R}$ Square & $\begin{array}{c}\text { Adjusted R } \\
\text { Square }\end{array}$ & $\begin{array}{c}\text { Std. Error of } \\
\text { the Estimate }\end{array}$ \\
\hline 1 &, $680^{a}$ &, 462 &, 437 & 2,129 \\
\hline
\end{tabular}
a. Predictors: (Constant), Kompetensi Profesional, Gender, Kompleksitas Tugas, Pengalaman Auditor
b. Dependent Variable: Audit Judgement

Tabel 4 menunjukkan hasil uji koefisien determinasi diperoleh nilai Adjusted $R$ Square sebesar 0,437. Hasil ini menunjukkan bahwa variabel gender, kompleksitas tugas, pengalaman auditor, dan kompetensi profesional mampu menjelaskan audit judgement sebesar 43,7 persen dan sisanya 56,3 persen dijelaskan oleh variabel lain yang tidak terdeteksi dalam penlitian ini. 


\section{Tabel 5 Hasil Uji Simultan}

\begin{tabular}{|ll|r|r|r|r|c|}
\multicolumn{7}{|c|}{ ANOVA $^{\text {a }}$} \\
Model & & $\begin{array}{c}\text { Sum of } \\
\text { Squares }\end{array}$ & df & Mean Square & \multicolumn{1}{c|}{$\mathrm{F}$} & Sig. \\
\hline 1 & Regression & 327,526 & 4 & 81,881 & 18,060 &, $000^{\text {b }}$ \\
& Residual & 380,834 & 84 & 4,534 & & \\
& Total & 708,360 & 88 & & & \\
\hline
\end{tabular}

a. Dependent Variable: Audit Judgement

b. Predictors: (Constant), Kompetensi Profesional, Gender, Kompleksitas Tugas, Pengalaman Auditor

Menurut table diatas pengujian regresi atau pengaruh variabel bebas secara bersama-sama terhadap variabel terikatnya dilakukan dengan menggunkana uji F. karena nilai $\mathrm{F}$ hitung $>\mathrm{F}$ tabel $(18,060>2,47)$, serta hasil nilai signifikansi 0,00 (lebih kecil dari 0,05). Maka dapat disimpulkan bahwa variabel bebas bersama-sama berpengaruh terhadap audit judgement.

\section{Uji Hipotesis Penelitian}

\section{Tabel 6 Hasil Perhitungan Uji t}

\begin{tabular}{|c|c|c|c|c|c|c|}
\hline \multicolumn{7}{|c|}{ Coefficients $^{a}$} \\
\hline \multirow{2}{*}{\multicolumn{2}{|c|}{ Model }} & \multicolumn{2}{|c|}{ Unstandardized Coefficients } & \multirow{2}{*}{$\begin{array}{c}\begin{array}{c}\text { Standardized } \\
\text { Coefficients }\end{array} \\
\text { Beta }\end{array}$} & \multirow[b]{2}{*}{$\mathrm{t}$} & \multirow[b]{2}{*}{ Sig. } \\
\hline & & $\mathrm{B}$ & Std. Error & & & \\
\hline \multirow[t]{5}{*}{1} & (Constant) & $-13,617$ & 3,001 & & $-4,538$ &, 000 \\
\hline & Gender &, 204 & ,468 &, 036 & ,435 &, 665 \\
\hline & Kompleksitas Tugas &, 149 & 051 &, 244 & 2,926 &, 004 \\
\hline & Pengalaman Auditor &, 217 & 044 & ,414 & 4,952 &, 000 \\
\hline & Kompetensi Profesional & 411 & 060 &, 568 & 6,795 &, 000 \\
\hline
\end{tabular}

a. Dependent Variable: Audit Judgement

Pengaruh gender terhadap audit judgement diperoleh nilai $\mathrm{t}$ hitung sebesar 0,435 > t table 1,986 dengan signifikansi sebesar 0,665 Nilai tersebut lebih besar dari 0,05 berarti dapat disimpulkan bahwa Hipotesis 1 ditolak. Pengaruh kompleksitas tugas terhadap audit judgement diperoleh nilai t hitung sebesar 2,926>t table 1,986 dengan signifikansi sebesar 0,004 Nilai tersebut lebih kecil dari 0,05 berarti dapat disimpulkan bahwa Hipotseis 2 diterima. Pengaruh pengalaman auditor tehadap audit judgement diperoleh nilai t hitung sebesar 4,952 > t table 1,986 dengan signifikansi sebesar 0,000 Nilai tersebut lebih kecil dari 0,05 berarti dapat disimpulkan bahwa Hipotesis 3 diterima. Pengaruh kompetensi profesional terhadap audit judgement diperoleh nilai t hitung sebesar 6,795 > t table 1,986 dengan signifikansi sebesar 0,000 Nilai tersebut lebih kecil dari 0,05 berarti dapat disimpulkan Hipotesis 4 diterima.

\section{HASIL PENELITIAN DAN PEMBAHASAN}

\section{Pengaruh Genderterhadap Audit Judgement}

Pengujian hipotesis pertama diperoleh nilai t hitung sebesar 0,435 > t table 1,986 dengan signifikansi sebesar 0,665 lebih besar dari 0,05. Hal tersebut menyatakan bahwa gende rtidak berpengaruh terhadap audit judgement. Hal ini menunjukkan bahwa perbedaan jenis kelamin antara laki-laki dan perempuan dengan perbedaan berbagai sifat dan karakter individu masing-masing tidak berpengaruh terhadap audit judgement yang diambil oleh auditor laki-laki dan perempuan. Auditor melakukan pemeriksaan berdasarkan prosedur dan standar audit 
yang telah ditetapkan sehingga baik auditor laki-laki maupun perempuan mengetahui saat pengambilan judgement yang sesuai dengan situasi yang terjadi.

Auditor laki-laki maupun perempuan diwajibkan menggunakan pertimbangan profesionalnya untuk menentukan hal-hal yang terkait dengan pemeriksaan karena tuntutan professionalism seseorang auditor semakinbesar. Auditor memberikan implikasi pada Kantor Akuntan Publik untuk tidak berorientasi pada suatu gender tertentu ketika melakukan perekrutan dan penugasan auditor. Dalam penelitian ini rata-rata responden lebih banyak jumlah auditor laki-laki daripada auditor perempuan dikarenakan bekerja sebagai akuntan cukup memakan tenaga fisik yang cukup besar, sehingga Kantor Akuntan Publik lebih banyak menggunakan tenaga kerja laki-laki.

\section{Pengaruh Kompleksitas Tugasterhadap Audit Judgement}

Pengujian hipotesis kedua diperoleh nilai t hitung sebesar 2,926 > t table 1,986 dengan signifikansi sebesar 0,004Nilai tersebut lebih kecil dari 0,05. Hal tersebut menyatakan bahwa kompleksitas tugas berpengaruh terhadap audit judgement. Mengetahui tugas yang berhubungan dengan seluruh fungsi bisnis klien akan membuat auditor mampu mengambil keputusan terhadap permasalahan selama pemeriksaan. Auditor mengetahui tugas khusus yang akan dikerjakan dan alasan mengerjakan tugas tersebut membuat auditor membuat planning pemeriksaan yang akan didahulukan jika ada permasalahan salah saji material laporan keuangan, bukti substantive yang minim dalam mendukung saldo piutang dan permasalahan dalam melakukan daftar konfirmasi yang dilakukan.

Seorang auditor mengetahui tugas yang harus dikerjakan, alasan tugas tersebut harus dikerjakan, mengetahui tugas khusus dalam pemeriksaan membuat auditor mengambil keputusan dengan tepat sesuai dengan Standart Profesi Akuntan Publik (SPAP) dan laporan yang dihasilkan sesuai dengan standart yang digunakan perusahaan klein.

\section{Pengaruh Pengalaman Auditor terhadap Audit Judgement}

Pengujian hipotesis ketiga diperoleh nilai t hitung sebesar 4,952 > t table 1,986 dengan signifikansi sebesar 0,000Nilai tersebut lebih kecil dari 0,05. Hal tesebut menyatakan bahwa pengalaman auditor berpengaruh terhadap audit judgement. Pengalaman yang dimiliki oleh auditor akan membuat keputusan yang dibuat sesuai dengan SPAP. Pengalaman, pengetahuan merupakan elemen penting dalam mengaudit karena dengan pengalaman yang dimiliki seorang auditor akan mampu mengidentifikasi permasalahan seperti penghilangkan akun konfirmasi karena klien tidak memperbolehkan dan kelengkapan bukti substantive saldo piutang yang kurang sehingga diperlukan keputusan yang tepat agak tidak menggangu pekerjaan.

Pengalaman auditor berpengaruh terhadap keputusan yang diambil jika terdapat salah saji material dalam laporan keuangan yang mengarah pada penyimpangan sebab akan ada penolakan dari klein. Pengalaman diimbangi dengan pelatihan dan kesempatan oleh KAP untuk mengikuti Continung Profesional Education (CPE) akan menjadikan auditor bekerja dengan lebih profesional.

\section{Pengaruh Kompentensi Profesional terhadap Audit Judgement}

Pengujian hipotesis keempat diperoleh nilai t hitung sebesar 6,795 > t table 1,986 dengan signifikansi sebesar 0,000Nilai tersebut lebih kecil dari 0,05. Hal tersebut menyatakan bahwa kompetensi profesional berpengaruh terhadap audit judgement. Setiap auditor memiliki keahlian untuk membuat keputusan dengan baik jika ada indikasi klien akan melakukan kecurangan dan pemalsuan dalam perhitungan persediaan.

Dalam melakukan pemeriksaan seorang auditor mengetahui teori organisasi agar prosedur pemeriksaan yang dilakukan sesuai dengan entitas pada perusahaan klien. Jika klien meminta untuk tidak melakukan konfirmasi terhadap beberapa akun yang di jadikan sampel sebaiknya auditor tidak menghilangkan akun tersebut dan dilakukan uji subsquent event untuk mengetahui peristiwa atau transaksi yang terjadi setelah tanggal necara. Seorang auditor melakukan pemeriksaan memiliki prosedur yang mengatur dalam menjal ankan pemeriksaan yang sudah disepakati oleh kedua pihak jadi data yang diperlukan auditor tidak ada permasalah dalam pemeriksaan. 


\section{Kesimpulan}

\section{PENUTUP}

Gender tidak berpengaruh terhadap audit judgement, sedangkan kompleksitas tugas, pengalaman auditor, kompetensi profesional berpengaruh terhadap audit judgement.

\section{Keterbatasan}

Penelitian ini memiliki beberapa keterbatasan dalam pelaksanaannya,diantaranya adalah sampel dalam penelitian ini terbatas, dikarenakan penyebaran kuesioner dilakukan kepada responden pada akhir tahun, yang merupakan jadwal kerja terpadat bagi auditor sebagai profesi yang mengaudit laporan keuangan perusahaanperusahaan kleinnya. Selain itu penelitian ini hanya menerapkan metode penyebaran kuesioner untuk mengumpulkan data penelitian. Penelitian ini tidak melakukan wawancara langsung terhadap responden, sehingga kesimpulan yang diambil hanya berdasarkan pada data yang dikumpulkan melalui penggunaan instrumen secara tertulis tanpa adanya konfirmasi langsung secara lisan kepada responden.

\section{Agenda Penelitian Selanjutnya}

Terkait dengan keterbatasan tersebut, maka disarankan penelitian selanjutnya sebaiknya dilakukan tidak pada masa sibuk auditor di Kantor Akuntan Publik (KAP) agar data yang diperoleh bisa optimal karena banyak auditor yang bersedia mengisi kuesioner dan penelitian tidak hanya menggunakan metode kuesioner saja, tetapi bisa menambahkan metode wawancara, sehingga dapat memperkuat jawaban dalam kuesioner, sehingga tidak terjadi perbedaan persepsi dalam menginterprestasikan pertanyaan dalam keuesioner.

\section{DAFTAR PUSTAKA}

Fitriana Rahayu, Kamaliah dan Susilatri. 2014. Pengaruh Kompleksitas Tugas, Tekanan Ketaatan, Tingkat Senioritas Auditor, Keahlian Auditor, Dan Hubungan Dengan Klien Terhadap Audit Judgement (Studi Pada Akuntan Publik di KAP Wilayah Sumatera). JOM FEKON. Vol.1, No.2, Oktober 2014.

Fitriani Seni dan Daljono. 2012. Pengaruh Tekanan Ketaatan, Kompleksitas Tugas, Pengetahuan Dan Persepsi Etis Terhadap Audit Judgement. Vol.1, No.1, Tahun 2012.

Ghozali, Imam. 2012. Aplikasi Analisis Multivariate dengan Program IBM SPSS 20. Universitas Diponegoro : Semarang.

Ikatan Akuntan Indonesia. 2001. Standar Profesional Akuntan Publik. Jakarta: Salemba Empat.

Mulyadi. 2002. Auditing. Edisi 6, Buku 1. Jakarta : Salemba Empat.

Pasanda Erna dan Natalia Paranoan. 2013. Pengaruh Gender, Kompleksitas Tugas, Tekanan Ketaatan, Pengalaman Auditor Terhadap Audit Judgement. ISSN 2086-7603, Jurnal Akuntansi Multiparadigma JAMAL. Vol.4, No.3, Malang, Desember 2013,Hal 330-507.

Pektra Stacia dan Ratnawati Kurnia. 2015. Pengaruh Gender, Kompleksitas Tugas, Tekanan Ketaatan, Pengalaman Auditor Terhadap Audit Judgement. Ultima Accounting, Vol.7, No.1, Juni 2015.

Primasari Nora Hilmia. 2015. Pengaruh Gender, Supervisi, Independensi, Kompetensi Profesional, Dan Pemahaman Atas Strandar Audit Terhadap Audit Judgement. ISSN : 2252 7141. Jurnal Akuntansi dan Keuangan. Vol.4, No.2, Oktober 2015.

PutraAkbar Muhammad Tamara dan Puspita Rani. 2016. Pengaruh Gender, Kompleksita Tugas, Pengalaman Auditor, Dan Kompetensi Profesional Terhadap Audit Judgement (Studi Empris Pada Auditor Kantor Akuntan Publik Di Wilayah DKI Jakarta dan Tangerang Periode 2016). ISSN 2252 7141. Vol.5, No.2, Oktober 2016. 
Putri Andini Rahmatika, Azwir Nasir dan Devi Safitri. 2017. Pengaruh Tekanan Anggaran Waktu, Kompleksitas Tugas, Pengetahuan Auditor, Dan Pengalaman Auditor Terhadap Audit Judgement ( Studi Kasus Pada KAP di Pekanbaru, Batan, dan Padang). JOM Fekon. Vol.4, No.1, Februari 2017.

Putri Febrina Prima, Kennedy dan Pipin Kurnia. 2015. Pengaruh Pengetahuan Auditor, Pengalaman Auditor, Kompleksitas Tugas, Locus of Control, Dan Tekanan Ketaatan Terhadap Audit Judgement (Studi Kasus Pada Perwakilan BPKP Provinsi Riau). Jom FEKON Vol.2, No.2, Oktober 2015.

Putri Pritta Amina dan Herry Laksito. 2013. Pengaruh Lingkungan Etika, Pengalaman Auditor, Dan Tekanan Ketaatan Terhadap Kualitas Audit Judgement. ISSN: 2337-3806. Vol.2, No.2, Tahun 2013, Hal 1-11.

Sofiani Maria Magdalena Oerip Liana dan Elisa Tjondro. 2014. Pengaruh Tekanan Ketaatan, Pengalaman Audit, Dan Audit Tenure Terhadap Audit Judgement. Tax \& Accounting Review. Vol.4, No.1, 2014.

Yendrawati Reni dan Dheane Kurnia Mukti. 2015. Pengaruh Gender, Pengalaman Auditor, Kompleksitas Tugas, Tekanan Ketaatan, Kemampuan Kerja Dan Pengetahuan Auditor Terhadap Audit Judgemnet. Jurnal Inovasi dan Keirausahaan. Vol.4, No.1, Januari 2015, Hal 1-8. 